\section{Pacific Northwest}

National Laboratory

Operated by Battelle for the

U.S. Department of Energy

\title{
Water Clarity Simulant for K East Basin Filtration Testing
}

\author{
A. J. Schmidt
}

January 2006

Prepared for the U.S. Department of Energy under Contract DE-AC05-76RL01830 


\title{
DISCLAIMER
}

This report was prepared as an account of work sponsored by an agency of the United States Government. Neither the United States Government nor any agency thereof, nor Battelle Memorial Institute, nor any of their employees, makes any warranty, express or implied, or assumes any legal liability or responsibility for the accuracy, completeness, or usefulness of any information, apparatus, product, or process disclosed, or represents that its use would not infringe privately owned rights. Reference herein to any specific commercial product, process, or service by trade name, trademark, manufacturer, or otherwise does not necessarily constitute or imply its endorsement, recommendation, or favoring by the United States Government or any agency thereof, or Battelle Memorial Institute. The views and opinions of authors expressed herein do not necessarily state or reflect those of the United States Government or any agency thereof.

\author{
PACIFIC NORTHWEST NATIONAL LABORATORY \\ operated by \\ BATTELLE \\ for the \\ UNITED STATES DEPARTMENT OF ENERGY \\ under Contract DE-AC05-76RL01830
}

Printed in the United States of America
Available to DOE and DOE contractors from the Office of Scientific and Technical Information,
P.O. Box 62, Oak Ridge, TN 37831-0062;
ph: (865) 576-8401
fax: $(865)$ 576-5728
email: reports@adonis.osti.gov

\begin{abstract}
Available to the public from the National Technical Information Service, U.S. Department of Commerce, 5285 Port Royal Rd., Springfield, VA 22161 ph: (800) 553-6847 fax: $(703) 605-6900$ email: orders@ntis.fedworld.gov online ordering: http://www.ntis.gov/ordering.htm
\end{abstract}

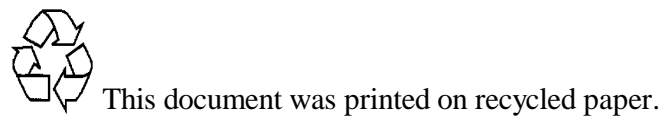




\title{
Water Clarity Simulant for K East Basin Filtration Testing
}

\author{
Prepared by: A. J. Schmidt
}

January 23, 2006 


\section{Contents}

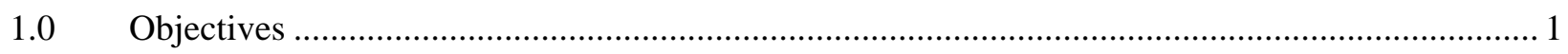

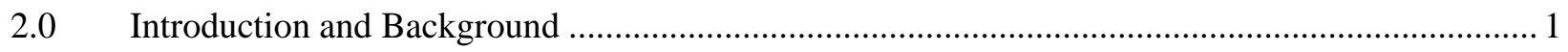

3.0 Key Parameters for Simulant Specification ..................................................................... 2

4.0 Basis for Simulant Particle Size Distribution Target ............................................................ 4

5.0 Basis for Simulant Chemical Compound Assignment........................................................... 4

6.0 Basis for Target Settled Simulant Water Content ................................................................ 7

7.0 Water Clarity Filtration Simulant Formulation.................................................................. 7

8.0 Example Basis for Total Quantity of Simulant Required for Testing ....................................... 10

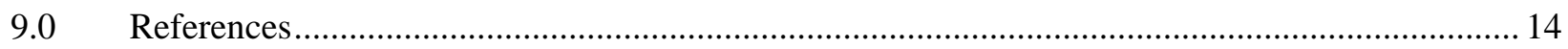

\section{Figures}

1 Scanning Electron Microscopy Images and Energy Dispersive Spectroscopy of Suspended Particles Collected from the KE Basin in September 2005 ......................................................... 3

$2 \quad$ Water Clarity Filtration Simulant with Flyash - No Sonication............................................... 11

3 Water Clarity Filtration Simulant with Flyash - After Sonication ......................................... 12

$4 \quad$ Scanning Electron Microscopy Images and Energy Dispersive Spectroscopy of Water Clarity Simulant Particles 


\section{Tables}

1 KE SCS Simulant Sludge Target Composition for KE SCS Testing .......................................... 4

2 Nominal Estimated Compound Distributions of KE NLOP Sludge Composites ..........................5

3 Expected Composition of Fine Material Captured in the Sand Filter, Based on Composition of the KE NLOP Decant and Top Layer Samples .............................................................. 6

$4 \quad$ Proposed Target Chemical Composition for the Water Clarity Filtration Simulant....................... 6

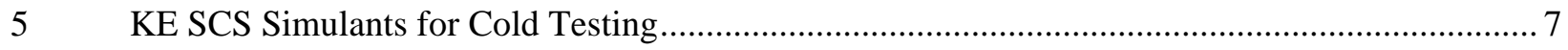

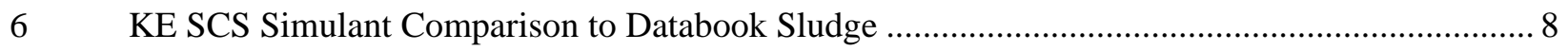

$7 \quad$ Solids Content of KE NLOP Segments Collected in December 2003...................................... 9

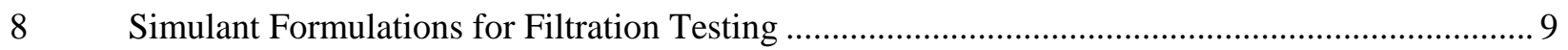

9 Summary of PSD Analyses Performed on Water Clarity Filtration Simulant ............................. 10 


\section{Water Clarity Simulant for K East Basin Filtration Testing}

\subsection{Objectives}

The objective of this document is to provide a simulant that mimics the behavior of the suspended solids in the K East (KE) Basin fuel storage pool. The simulant will be used to evaluate alternative filtration apparatus to improve Basin water clarity and to possibly replace the sandfilter. It is possible that the filtration apparatus could also be used to remove the suspended solids in the stream collected by a KE Sludge Consolidation System (SCS) skimmer.

The simulant was formulated based on the simulant objectives, the key identified parameters important to filtration, the composition and character of the KE Basin suspended sludge particles, and consideration of properties of surrogate materials.

This document was prepared by the Pacific Northwest National Laboratory (PNNL) for Fluor Hanford (FH) and has been cleared through PNNL's Information Release (IR) process for limited distribution (i.e., FH will provide further distribution).

\subsection{Introduction and Background}

Two water-filled concrete pools [KE and K West (KW) Basins] in the 100K Area of the Hanford Site contained over 2100 metric tons of N Reactor fuel elements stored in aluminum or stainless steel canisters. Removal of fuel from the Basins was essentially completed in 2004. During the time that the fuel was stored (mid 1970s to 2004), approximately $52 \mathrm{~m}^{3}$ of heterogeneous solid material (sludge) accumulated in the canisters, as well as on the floor and in the associated pits. This sludge consists of various proportions of fuel particulate (oxidized and metallic uranium), canister corrosion products (i.e., various iron and aluminum oxy-hydrates), sand filter backwash, windblown material, miscellaneous constituents such as ion exchange material (both organic and inorganic), and paint chips (Makenas et al. 1996-99). By definition, material less than 0.25 -inch $(6350 \mu \mathrm{m})$ in any two dimensions is considered "sludge." Greater than $25 \%$ of the sludge volume is comprised of fine particles less than $10 \mu \mathrm{m}$ (Schmidt 2005).

Under the current sludge management plan, the KE sludge is being removed (by suction) from the floor and pits, and contained in large, free-standing containers located underwater in pits (to isolate the sludge from the Basin). During sludge containerization activities, a polymer flocculant may be added to the sludge slurry to enhance sludge settling and speed the rate of clarification. The containers, associated pumps, and the flocculant make up and injection systems are collectively referred to as the KE Sludge Consolidation System (SCS). During sludge containerization, a fraction of the fine particulate in the sludge overflows the SCS containers and enters the Basin water. [Note: A skimmer system may be installed to direct the overflow from the SCS containers to an existing sandfilter.] In addition to the SCS container overflow, suspended particulate is also generated from other ongoing Basin activities including sludge retrieval, debris removal, and equipment installation. This suspended particulate increases Basin water turbidity and total alpha concentrations near and above the pool surface. 
To improve KE Basin water clarity, the K Basins Closure (KBC) Project is considering adding a filtration system to augment the existing water treatment system. The purpose of this letter report is to provide a simulant that mimics the behavior of the suspended solids in the KE Basin Pool and provides the basis of the selected simulant composition.

\subsection{Key Parameters for Simulant Specification}

The key parameters identified that affect filterability of suspended particulate and filtercake removal (i.e., from backwashable filters) are: particle size distribution, particle morphology/shape, chemical composition, compressibility/permeability, and shear strength of the resulting filtercake. These parameters will affect particle removal efficiency, filter loading, and filtercake removal (from a backwashable filter). The approaches used to specify the key parameters for the Water Clarity Simulant are summarized in this section.

\section{$\underline{\text { Particle Size Distribution (PSD) }}$}

The PSD (volume basis) for the simulant should approximately match the PSD of the suspended solids in water samples taken for the center of the KE Basin (see Section 4.0).

Range: 0.2 to $10 \mu \mathrm{m} ; \mathrm{DP}_{50}$ (i.e., medium particle size - volume basis) $=1.5$ to $3.5 \mu \mathrm{m}$.

\section{$\underline{\text { Particle Shape }}$}

Particle shape was not specifically targeted for simulant development; however, where possible, appropriate phases were selected (e.g., gibbsite has been the most frequently identified aluminum hydroxide phase identified in the K Basin sludge). Also, a mixture of general particle shapes has been specified (e.g., ground silica composed of irregular/angular particles; flyash - which is generally comprised of spherical particles). Scanning Electron Microscopy (SEM) images of actual K Basin suspended solids (captured on a 2- $\mu \mathrm{m}$ filter), displayed in Figure 1, show both irregular agglomerates and rounded shapes.

\section{Chemical Composition}

Simulant was developed to match the general composition and predominant chemical phases of KE Containerized sludge and KE NLOP Decant sludge samples.

\section{Compressibility/Permeability and Shear Strength of Filter Cake}

No data is available on compressibility, permeability, or shear strength of a representative $\mathrm{K}$ Basin particulate filtercake. However, measurements performed on KE Basin sludge show that settled sludge contains 75 vol\% water (Schmidt 2005). Therefore, upon settling, the simulant should exhibit water content greater than 75 vol\%. 


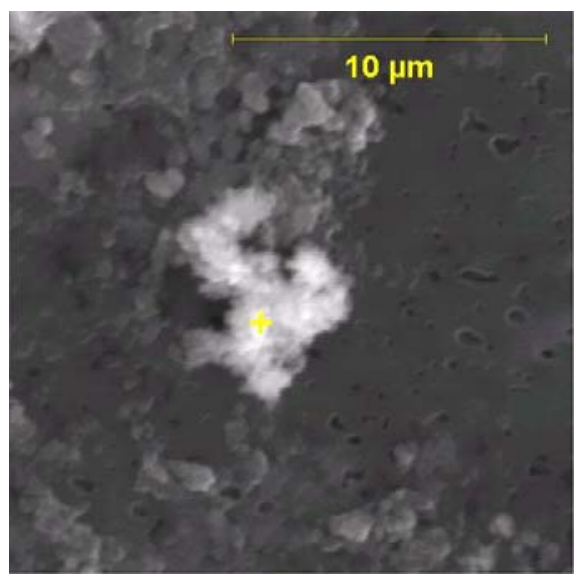

1A Iron-Rich Agglomerate

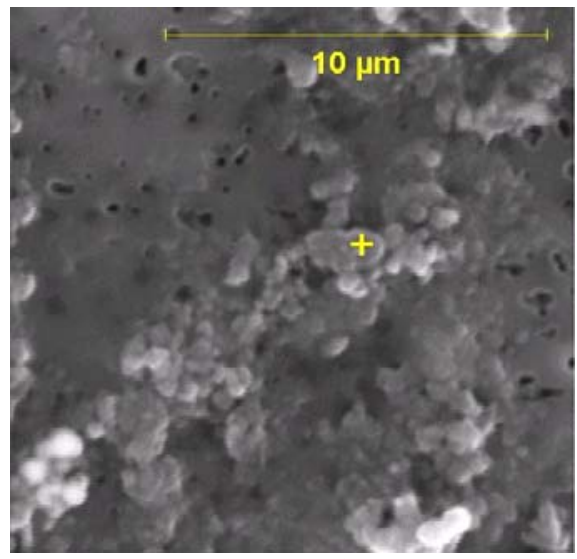

1B Aluminum-Rich Agglomerate

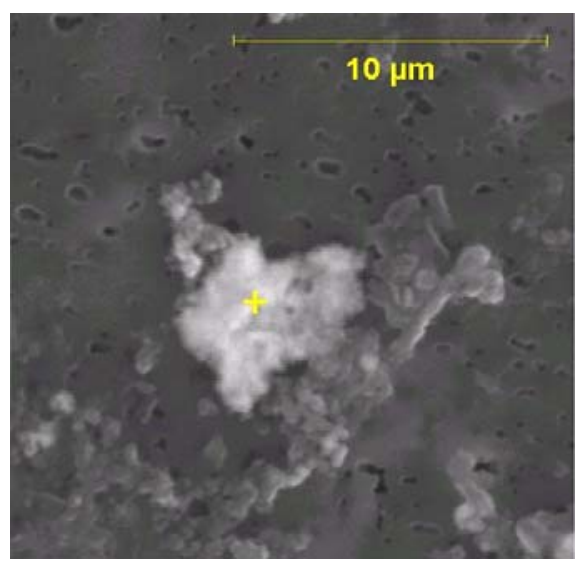

1C Uranium-Rich Agglomerate
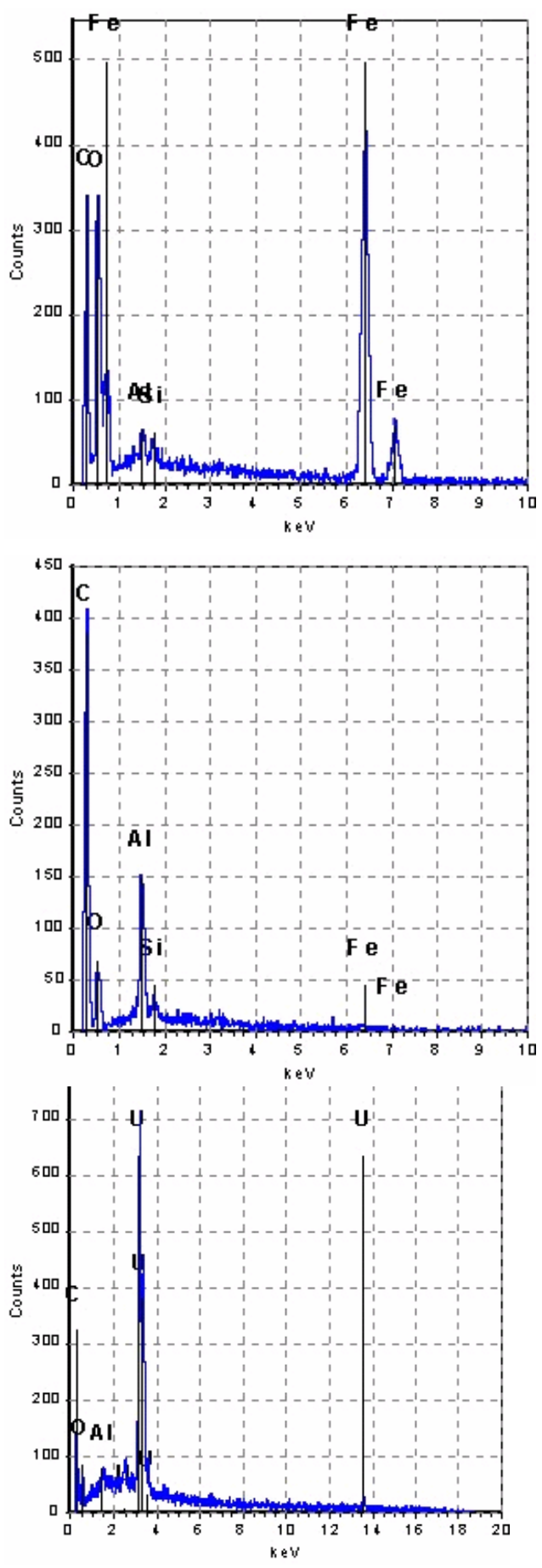

Figure 1. Scanning Electron Microscopy Images and Energy Dispersive Spectroscopy of Suspended Particles Collected from the KE Basin in September 2005. Particles were captured on a $2.0 \mu \mathrm{m}$ (absolute) Nucleopore filter. SEM analysis was performed by Analytical Technical Services, Hanford. 


\subsection{Basis for Simulant Particle Size Distribution Target}

In November 2004, KE Basin water samples were taken at the center of the Basin from four depths: at the surface, at approximately 6 feet, approximately 10 feet, and approximately 14 feet. These samples were subjected to particle size distribution analyses. ${ }^{(a)}$

The volume-based PSDs for all four samples were similar. On average, the initial PSDs spanned a range of 0.51 to $10.2 \mu \mathrm{m}$ (10- to $90 \%$ - undersize; i.e., $10 \mathrm{vol} \%$ of the particles less than $0.51 \mu \mathrm{m}$ and $10 \mathrm{vol} \%$ of the particles greater than $10.2 \mu \mathrm{m}$ ) with a median value of $2.5 \mu \mathrm{m}$ (average of four samples). Additional PSDs measured after extended stirring, pumping, and sonication shifted to slightly smaller diameters spanning an average range of 0.46 to $8.8 \mu \mathrm{m}$ (10- to $90 \%$ - undersize) with an median value of $1.8 \mu \mathrm{m}$ (average of four samples).

\subsection{Basis for Simulant Chemical Compound Assignment}

The chemical composition of KE Containerized sludge was estimated ${ }^{(b)}$ based on the sludge flowsheet document (Pearce 2001), which includes projected chemical compounds in the sludge. From this basis, the target simulant composition in Table 1 was calculated for the KE SCS testing conducted in the 305 Building (Crocker 2005).

Table 1. KE SCS Simulant Sludge Target Composition for KE SCS Testing

\begin{tabular}{|l|c||}
\hline \multicolumn{1}{|c|}{ Component } & $\begin{array}{c}\text { Wt\% } \\
\text { (dry solids basis) }\end{array}$ \\
\hline $\mathrm{Fe}(\mathrm{OH})_{3}$ & 42 \\
\hline $\mathrm{Al}(\mathrm{OH})_{3}$ & 15 \\
\hline $\mathrm{U}$ oxides & 15 \\
\hline Silica & 28 \\
\hline
\end{tabular}

While Table 1 provides a general target composition for all KE SCS sludge, it is not specific to the composition of particles that stay suspended within the Basin water. The composition of suspended sludge in the KE Basin is expected to be similar to the low density material in the KE NLOP sludge (i.e., suspended material collected by pool skimmers, captured by the sandfilter, and subsequently backflushed into the KE NLOP). In December 2003, a KE NLOP sludge core sample was isolated and recovered in three approximately equal separate core segments (Top, Middle, and Bottom) (Mellinger et al. 2004; Shelor et al. 2004). After the Top segment was collected, it was allowed to settle for about 15 minutes, and then excess water was decanted. Significant suspended material was observed in this decant water and it was therefore maintained as a separate sample (i.e., KE NLOP Decant sample) then shipped along with other samples to the lab for analysis. Some properties were measured (\% water, density) on the four samples, and then they were dried and analyzed.

(a) “Measurement of Particle Size Distributions in 105-KE Basin Water Samples," CH2M-0403713, transmitted from WS Calloway, CH2M HILL, to RM Jochen, FH, December 2, 2004, CH2M HILL Hanford Group, Inc., Richland, WA.

(b) Barrington, CA. "KE SCS Sludge Simulant Formulation.” Calculation Number A21A-CH-004, Rev. 2, Flour Federal Services, Richland, WA. 
The elemental constituents in KE NLOP sludge sample material collected in 2003 were determined by inductively coupled plasma - atomic emission spectroscopy (ICP-AES) (Shelor et al. 2004), and the predominant elements (> $0.1 \mathrm{wt} \%$ - dry solids basis) were $\mathrm{Al}, \mathrm{Ca}, \mathrm{Fe}, \mathrm{Mg}, \mathrm{P}, \mathrm{Si}, \mathrm{U}$, and $\mathrm{Zn}$. Other elements found in lower concentrations (generally below $0.1 \mathrm{wt} \%$ or $1000 \mu \mathrm{g} / \mathrm{g}$ dry sludge) include Ba, $\mathrm{Cd}, \mathrm{Cr}, \mathrm{Cu}, \mathrm{K}, \mathrm{Mn}, \mathrm{Na}, \mathrm{Ni}, \mathrm{Pb}, \mathrm{Sr}, \mathrm{Ti}, \mathrm{V}$, and Zr. The radionuclide concentrations in the KE NLOP sludge were measured and are presented in Shelor et al. (2004) and Schmidt (2005). The predominant elemental concentrations were converted to compound concentrations based on assumed phases or chemical forms (primarily oxides, hydroxides, or in the case of calcium and magnesium, carbonates) thought most likely to be present in the sludge (Table 2). The indicated uranium phase, $\mathrm{UO}_{2.56} \cdot \mathrm{H}_{2} \mathrm{O}$, is a mixture of $\mathrm{UO}_{2}, \mathrm{UO}_{2.25}$, and $\mathrm{UO}_{3} \cdot 2 \mathrm{H}_{2} \mathrm{O}$ in a 25:25:50 mol\% ratio, respectively. The uranium phase identities and distribution were suggested by Schmidt and Baker (2004). ${ }^{\text {(a) }}$ The $\mathrm{Al}(\mathrm{OH})_{3}$ (gibbsite, bayerite, nordstrandite), $\mathrm{CaCO}_{3}$ (calcite), $\mathrm{FeOOH}$ (goethite, lepidocrocite), and $\mathrm{UO}_{2.56} \cdot \mathrm{H}_{2} \mathrm{O}$ (representing the uraninite/schoepite mixture) all have been identified in prior KE Basins sludge characterization campaigns (Makenas et al. 1996-99).

Table 2. Nominal Estimated Compound Distributions of KE NLOP Sludge Composites

\begin{tabular}{|c|c|c|c|c|c|c|c|c|c|}
\hline \multirow{2}{*}{ Sludge Horizon } & \multicolumn{9}{|c|}{ Estimated Concentration, ${ }^{(\mathrm{a})}$ Dry Wt $\%$} \\
\hline & $\mathrm{Al}(\mathrm{OH})_{3}$ & $\mathrm{CaCO}_{3}$ & FeOOH & $\mathrm{MgCO}_{3}$ & $\mathbf{P}_{2} \mathbf{O}_{5}$ & $\mathrm{SiO}_{2}$ & $\mathrm{UO}_{2.56} \cdot \mathrm{H}_{2} \mathrm{O}$ & ZnO & Sum $^{(\mathbf{b})}$ \\
\hline KENLOP-1 & 10.96 & 2.20 & 10.04 & 0.40 & 0.10 & 77.23 & 2.61 & 0.27 & 103.8 \\
\hline KENLOP-1 Dup & 11.74 & 2.48 & 11.69 & 0.44 & 0.12 & 77.87 & 3.14 & 0.32 & 107.8 \\
\hline KENLOP-Comp $^{(c)}$ & 11.35 & 2.34 & 10.87 & 0.42 & 0.11 & 77.55 & 2.88 & 0.30 & 105.8 \\
\hline KENLOP-Decant & 40.03 & 1.34 & 43.59 & 2.00 & 0.73 & 25.67 & 19.22 & 0.69 & 133.3 \\
\hline KENLOP-Top & 27.55 & 1.20 & 31.66 & 0.70 & 0.45 & 9.52 & 14.23 & 0.21 & 85.5 \\
\hline KENLOP-Mid & 15.29 & 0.49 & 10.10 & 0.33 & 0.14 & 55.19 & 7.99 & 0.10 & 89.6 \\
\hline KENLOP-Bot & 8.24 & 2.30 & 8.75 & 0.35 & 0.07 & 66.53 & 1.01 & 0.35 & 87.6 \\
\hline Sludge Horizon & \multicolumn{9}{|c|}{ Normalized Concentration, Dry Wt\% } \\
\hline KENLOP-Comp & 10.72 & 2.21 & 10.27 & 0.40 & 0.11 & 73.29 & 2.72 & 0.28 & 100.0 \\
\hline KENLOP-Decant & 30.04 & 1.00 & 32.71 & 1.50 & 0.55 & 19.26 & 14.42 & 0.52 & 100.0 \\
\hline KENLOP-Top & 32.21 & 1.40 & 37.02 & 0.82 & 0.53 & 11.13 & 16.64 & 0.25 & 100.0 \\
\hline KENLOP-Mid & 17.06 & 0.55 & 11.27 & 0.36 & 0.16 & 61.58 & 8.91 & 0.11 & 100.0 \\
\hline KENLOP-Bot & 9.40 & 2.63 & 9.99 & 0.40 & 0.08 & 75.95 & 1.15 & 0.40 & 100.0 \\
\hline \multicolumn{10}{|c|}{$\begin{array}{l}\mathrm{Ca}, \mathrm{Fe}, \mathrm{Mg}, \mathrm{P}, \mathrm{U} \text {, and } \mathrm{Zn} \text { analyses are based on acid leach of dry sludge; } \mathrm{Al} \text { is based on acid leach of the dry sludge plus } \\
\mathrm{KOH} / \mathrm{KNO}_{3} \text { fusion of the acid leach residue; and } \mathrm{Si} \text { is based on } \mathrm{KOH} / \mathrm{KNO}_{3} \text { fusion digest of dry sludge only. }\end{array}$} \\
\hline \multicolumn{10}{|c|}{$\begin{array}{l}\text { (a) The compound assignments were based upon phase identification analyses (performed on other } \mathrm{K} \text { Basin floor samples) and } \\
\text { engineering judgment. The assignment of phosphorous to } \mathrm{P}_{2} \mathrm{O}_{5} \text { was made to express its likely existence as a phosphate } \\
\text { mineral but to keep it separate from its association with other analytes (e.g., with Ca as brushite, } \mathrm{CaHPO}_{4} \cdot 2 \mathrm{H}_{2} \mathrm{O} \text { ). } \\
\text { (b) The sum provides a gauge of the estimated error in the assumed compound concentrations. } \\
\text { (c) Average of KENLOP-1 and KENLOP-1 Dup aliquots from the KENLOP-Comp material. }\end{array}$} \\
\hline
\end{tabular}

Based on the Decant layer and Top layer, the fine suspended material captured by sandfilter can be approximately represented as the composition provided in Table 3 . The composition in Table 3 is similar to that in Table 1, with the exception that the $\mathrm{Al}(\mathrm{OH})_{3}$ concentration is higher in the KE NLOP Decant and Top Layer and the silica is lower.

(a) Schmidt AJ, and RB Baker. 2004. "Revised Design and Safety Basis Values for Physical Properties, Radionuclides, and Chemical Composition of Sludge in the KE Basin North Loadout Pit." PNNL Letter Report 46497-RPT03, Rev. 1, transmitted to W. W. Rutherford (FH) and J. P. Sloughter (NHC) by K. L. Silvers (PNNL) on February 24, 2004, via transmittal letter 46497-L05. 
Table 3. Expected Composition of Fine Material Captured in the Sand Filter, Based on Composition of the KE NLOP Decant and Top Layer Samples

\begin{tabular}{|l|c||}
\hline \multicolumn{1}{|c|}{ Component } & $\begin{array}{c}\text { Wt\% } \\
\text { (dry solids basis) }\end{array}$ \\
\hline $\mathrm{FeOOH}$ & 35 \\
\hline $\mathrm{Al}(\mathrm{OH})_{3}$ & 30 \\
\hline $\mathrm{U}$ oxides & 15 \\
\hline Silica & 15 \\
\hline Balance & 5 \\
\hline
\end{tabular}

Based on a comparison of the two compositions (Table 1 and Table 3), the composition shown in Table 4 has been selected as the target chemical composition of the Water Clarity Filtration Simulant.

Table 4. Proposed Target Chemical Composition for the Water Clarity Filtration Simulant

\begin{tabular}{||l|c||}
\hline \multicolumn{1}{|c|}{ Component } & $\begin{array}{c}\text { Wt\% } \\
\text { (dry solids basis) }\end{array}$ \\
\hline Iron oxyhydroxides & 40 \\
\hline $\mathrm{Al}(\mathrm{OH})_{3}$ & 30 \\
\hline U oxides & 15 \\
\hline Silica & 15 \\
\hline
\end{tabular}

From the target chemical composition given in Table 1, simulants were developed for cold testing the KE SCS System in the 305 Building (Crocker 2005). The composition and properties of the KE SCS cold testing simulants are summarized in Tables 5 and 6, respectively. Flyash was used as a non-radioactive surrogate for uranium oxides. For the Water Clarity Filtration simulant, a formulation using components similar to those given for Simulant A/B (Table 5) is recommended. As indicated by the PSDs shown in Table 6, the specific components used for the Water Clarity Filtration Simulant must exhibit a finer PSD. It is noted that the settled sludge from both Simulants A and A/B do not exhibit significant shear strength. The effect of the shear strength of a resulting filtercake and its impact on filter backwashability has not been evaluated. 
Table 5. KE SCS Simulants for Cold Testing

\begin{tabular}{|c|c|c|c|}
\hline Component & $\begin{array}{c}\text { 40\% FeOOH } \\
\text { Modified } \\
\text { Simulant B, } \\
\text { Wt } \%\end{array}$ & $\begin{array}{c}40 \% \mathrm{Fe}(\mathrm{OH})_{3} \\
\text { Simulant } \mathrm{A}, \\
\text { Wt\% }\end{array}$ & $\begin{array}{c}20 \% \mathrm{Fe}(\mathrm{OH})_{3} \\
20 \% \mathrm{FeOOH} \\
\text { Simulant A/B, } \\
\text { Wt } \%\end{array}$ \\
\hline $\begin{array}{l}\mathrm{Fe}(\mathrm{OH})_{3} \text { Pressure Cake, } \\
\quad-23 \mathrm{wt} \% \text { solids. (Blue Grass } \\
\text { Chemical Specialties, L. P.) }\end{array}$ & 0 & 40 (dry) & 20 (dry) \\
\hline Ferric oxide hydroxide ${ }^{(a)}$ (Shepherd) & 40 & 0 & 20 \\
\hline Blow Sand & 30 & 20 & 20 \\
\hline $\mathrm{Al}(\mathrm{OH})_{3} \mathrm{AC} 440^{(\mathrm{b})}$ & 15 & 15 & 15 \\
\hline $\begin{array}{l}\text { Class F Flyash (use as surrogate for } \\
\text { U oxides) }\end{array}$ & 15 & 15 & 15 \\
\hline Bentonite Supergel X & 0 & 10 & 10 \\
\hline TOTAL & 100 & 100 & 100 \\
\hline
\end{tabular}

\subsection{Basis for Target Settled Simulant Water Content}

Table 7 provides data on the measured and calculated solids concentration in the "settled" KE NLOP Decant and Segments samples. The apparent solids content of the wet Decant sample was $0.0075 \mathrm{~g}$ solids $/ \mathrm{cm}^{3}$, however; this value is not defensible, since the sample may not have been completely settled when measured (i.e., with additional settling time, sample may have consolidated to a higher solids content). The solids content in the Top and Middle segments were also low, and ranged from about 0.05 to $0.13 \mathrm{~g}$ solids $/ \mathrm{cm}^{3}$. The solids content in the Bottom segment, which was comprised mostly of sand, ranged from 0.36 to $0.47 \mathrm{~g}$ solids $/ \mathrm{cm}^{3}$. In comparison to the KE NLOP samples, the design basis solids content for settled KE Floor and Canister sludge, $0.65 \mathrm{~g} / \mathrm{cm}^{3}$ and $1.15 \mathrm{~g} / \mathrm{cm}^{3}$, respectively, are considerably higher.

The high water content and low solids content of the KE NLOP Decant and Top layer indicated that the Water Clarity Filtration Simulant, upon settling, should have high water content.

\subsection{Water Clarity Filtration Simulant Formulation}

From the information provided above, the formulation for the Water Clarity Filtration Simulant has been developed and is provided in Table 8 . In addition to the formulation, Table 8 also provides specific information on the components (item number and vendor) and the amount of each component required to prepare $30 \mathrm{~kg}$ (dry basis) of simulant. Flyash is included in the formulation to represent uranium oxides. Flyash (Class F Centralia Flyash) has been used in a number of K Basin sludge simulants, including the successful testing of the backwashable filter used for the Consolidated Sludge Sampler (Hecht 1999). However, alkali metal oxides (e.g., $\mathrm{Na}_{2} \mathrm{O}$ ) can leach from flyash and raise the solution $\mathrm{pH}$ if the volume of water involved is relatively limited. 
Table 6. KE SCS Simulant Comparison to Databook Sludge

\begin{tabular}{|c|c|c|c|c|c|c|}
\hline \multirow[b]{2}{*}{ Properties } & \multicolumn{3}{|c|}{ Flocculant Simulant } & \multicolumn{3}{|c|}{$\begin{array}{c}\text { Nominal KE Floor and Canister } \\
\text { Sludge }\end{array}$} \\
\hline & $\begin{array}{l}\text { Modified B } \\
40 \% \text { FeOOH }\end{array}$ & $\begin{array}{c}\text { Simulant } \mathrm{A} \\
40 \% \mathrm{Fe}(\mathrm{OH})_{3}\end{array}$ & $\begin{array}{c}\text { Simulant } \mathrm{A} / \mathrm{B} \\
20 \% \mathrm{Fe}(\mathrm{OH})_{3} \\
20 \% \mathrm{FeOOH}\end{array}$ & $\begin{array}{c}\text { KE } \\
\text { Floor }^{(a)}\end{array}$ & $\begin{array}{c}\text { KE } \\
\text { Canister }^{(a)}\end{array}$ & $\begin{array}{c}\text { 6.9\% Canister } \\
\text { 93.1\% Floor } \\
\text { Sludge } \\
\text { Mixture }\end{array}$ \\
\hline Settled Density, $\mathrm{g} / \mathrm{cm}^{3}$ & 1.76 & 1.15 & 1.21 & 1.4 & 1.9 & 1.43 \\
\hline Volume Fraction water & 0.53 & 0.928 & 0.897 & 0.75 & 0.75 & 0.75 \\
\hline Total Solids, $\mathrm{g} / \mathrm{cm}^{3}$ & 1.23 & 0.22 & 0.31 & 0.65 & 1.15 & 0.68 \\
\hline $\mathrm{Wt} \%$ Solids & 70 & 19.3 & 25.9 & 46.4 & 60.5 & 47.7 \\
\hline Ave. Particle Density, $\mathrm{g} / \mathrm{cm}^{3}$ & 2.62 & 3.08 & 3.04 & 2.6 & 4.6 & 2.73 \\
\hline Shear Strength, $\mathrm{Pa}$ & 1600 & 12.07 & 2.4 & $1-8200$ & $1-8200$ & $1-8200$ \\
\hline \multicolumn{7}{|l|}{ Particle Size } \\
\hline percent less than $1410 \mu \mathrm{m}$ & 100 & 100 & 100 & 86 & 85 & 86 \\
\hline percent less than $500 \mu \mathrm{m}$ & 95 & $99.9^{(\mathrm{b})}$ & $100^{(\mathrm{b})}$ & 79 & 72 & 78 \\
\hline percent less than $100 \mu \mathrm{m}$ & 70 & $93.1^{(\mathrm{b})}$ & $100^{(\mathrm{b})}$ & 65 & 61 & 65 \\
\hline percent less than $10 \mu \mathrm{m}$ & 28 & 55.6 & 53.6 & 28 & 25 & 28 \\
\hline percent less than $1 \mu \mathrm{m}$ & 1.8 & 6.43 & 5.02 & 3 & 3 & 3 \\
\hline $\begin{array}{l}\text { Estimated Settling Time, }{ }^{(\mathrm{c})} \\
\text { min }\end{array}$ & $\begin{array}{l}\sim 30 \min ^{(\mathrm{d})}: \\
\text { cloudy }\end{array}$ & $\sim 60$ & cloudy $100 \mathrm{hr}$ & $\sim 60$ & $\sim 60$ & $\sim 60$ \\
\hline \multicolumn{7}{|l|}{ Uranium Compositions } \\
\hline Uranium total, $\mathrm{g} / \mathrm{cm}^{3}$ & 0 & 0 & 0 & 0.06 & 0.77 & 0.11 \\
\hline Uranium total, wt\% (solids) & 0 & 0 & 0 & 9.23 & 67 & 15.9 \\
\hline $\begin{array}{l}\text { (a) Properties from Schmidt (20 } \\
\text { (b) Subsample analyzed most li } \\
\text { (c) Time required for sludge in } \\
\text { (d) In a } 500 \mathrm{ml} \text { cylinder }(\sim 11 \mathrm{in}\end{array}$ & and Plys and S & $\begin{array}{l}\text { midt (2005). } \\
\text { incentration of } b\end{array}$ & led. & & 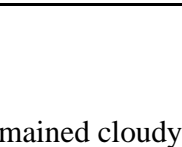 & \\
\hline
\end{tabular}

Since the selection of specific components is based partially on past experience, substitution of the specific components identified in Table 8 should not be made, unless the proposed substitute component is characterized and validated.

Based on the compositions given in Table 8, a simulant was prepared at a solids concentration of $20,000 \mathrm{mg} / \mathrm{L}$. After preparation, the simulant was mixed and settling behavior was observed. The simulant remained cloudy, and no distinct sludge layer could be discernable after 72 hours. Particle size distribution measurements were performed and are provided in Figures 2 and 3. Table 9 summarizes the PSD measurement results. In summary, the $\mathrm{Dp}_{50}$ (median particle size - volume basis) of the simulant is similar to that of the actual suspended particulate collected from the K Basin pool water samples. The simulant PSD includes a larger fraction of particles that are greater than $10 \mu \mathrm{m}$ as compared with the KE Basin water samples. However, it is expected that if the stream from the KE SCS skimmer is processed through the filtration system, the PSD of the suspended solids will increase. 
Table 7. Solids Content of KE NLOP Segments Collected in December 2003

\begin{tabular}{|c|c|c|c|c|}
\hline \multirow[b]{2}{*}{$\begin{array}{c}\text { Sample } \\
\text { Segment }{ }^{(a)}\end{array}$} & \multirow[b]{2}{*}{$\begin{array}{l}\text { Wt\% } \\
\text { Water }\end{array}$} & \multirow[b]{2}{*}{$\begin{array}{c}\text { Settled } \\
\text { Density, } \\
\text { g/cm }\end{array}$} & \multicolumn{2}{|c|}{$\begin{array}{l}\text { Dry Solids Concentration } \\
\end{array}$} \\
\hline & & & 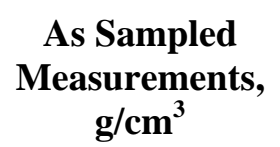 & $\begin{array}{c}\text { Alternative } \\
\text { Calculation, } \\
\text { (b) }^{\left(\mathbf{g}^{3}\right.}{ }^{3}\end{array}$ \\
\hline Decant & 99.3 & 1.00 & 0.0075 & \multirow{2}{*}{0.0532} \\
\hline Top & 94.8 & 1.00 & 0.052 & \\
\hline Middle & 88.4 & 1.10 & 0.13 & 0.0609 \\
\hline Bottom & 70.6 & 1.23 & 0.36 & 0.468 \\
\hline Composite & 71.9 & 1.21 & 0.34 & 0.253 \\
\hline \multicolumn{5}{|c|}{$\begin{array}{l}\text { Data from Shelor et al. 2004. SNF-22059, Attachment 21, Table } 1 . \\
\text { (a) Isolated sample core was collected roughly in } 3 \text { equal volume segments, top, middle } \\
\text { bottom. Decant is material that did not readily settle in material collected from top } \\
\text { segment. } \\
\text { (b) Based on solids contained within core segment. Each segment was } 2 \text { in. diameter and } \\
\text { approximately } 12 \text { in. long before sludge was disturbed. }\end{array}$} \\
\hline
\end{tabular}

Table 8. Simulant Formulations for Filtration Testing

\begin{tabular}{|c|c|c|c|c|}
\hline Simulant Component & Wt $\%$ & $\begin{array}{c}\mathrm{Dp}_{50} \\
\boldsymbol{\mu m}\end{array}$ & $\begin{array}{l}\text { Quantity } \\
\text { Needed, } \\
\text { kg }\end{array}$ & $\begin{array}{l}\text { Vendor/Supplier Contact } \\
\text { Info }\end{array}$ \\
\hline $\begin{array}{l}\mathbf{F e}(\mathbf{O H})_{3}^{\left({ }^{(a)}\right.} \\
\text { Code } 11177,99.5 \% \\
13 \text { wt } \% \text { slurry }\end{array}$ & $20 \%$ & 0.3 & 46.15 & $\begin{array}{l}\text { Noah Tech Corp, TX } \\
\text { Phone: (210) 691-2000 }\end{array}$ \\
\hline $\begin{array}{l}\text { Ferric oxide hydroxide } \\
\text { Product Number } 2615\end{array}$ & $20 \%$ & 12.9 & 6.00 & $\begin{array}{l}\text { Shepherd Chem. Co. OH } \\
\text { (513) } 731-1110 \\
\text { www.shepchem.com }\end{array}$ \\
\hline $\begin{array}{l}\text { Al(OH) })_{3}-\text { Gibbsite } \\
\text { SpaceRite, S-3 }\end{array}$ & $30 \%$ & 1.1 & 9.00 & $\begin{array}{l}\text { Almatis Inc. } \\
\text { (800) 643-8771 } \\
\text { AlmatisCustServ.Americas } \\
\text { @ almatis.com }\end{array}$ \\
\hline $\begin{array}{l}\mathrm{SiO}_{2} \\
\text { Min-U-Sil-5 }\end{array}$ & $15 \%$ & 1.7 & 4.50 & $\begin{array}{l}\text { US Silica, WV } \\
\text { (800) 258-2500 } \\
\text { berkcustsvc@ussilica.com } \\
\end{array}$ \\
\hline Class F Centralia Flyash & $15 \%$ & 24.4 & 4.50 & $\begin{array}{l}\text { Glacier Northwest, Tacoma } \\
\text { (253) 896-4650 } \\
\text { Central Pre-Mix Pasco } \\
\text { (509) 545-8405 }\end{array}$ \\
\hline \multicolumn{5}{|c|}{$\begin{array}{l}\text { (a) } \mathrm{Fe}(\mathrm{OH})_{3} \text { is sold as a } 13 \mathrm{wt} \% \text { slurry. Therefore to obtain required quantity, } \mathrm{kg} \text { (dry) mass, must be divided } \\
\text { by } 0.13 \text {. } \\
\text { (b) Quantity needed to prepare } 30 \mathrm{~kg} \text { (dry weight basis) of simulant. }\end{array}$} \\
\hline
\end{tabular}


Table 9. Summary of PSD Analyses Performed on Water Clarity Filtration Simulant

\begin{tabular}{|c|c|c|c|}
\hline \multirow{3}{*}{ Sample } & \multicolumn{3}{|c|}{ In Distribution Based on Particle Volume } \\
\hline & $10 \%$ & $\begin{array}{c}50 \% \\
\text { (i.e., } \mathrm{Dp}_{50} \text { ) }\end{array}$ & $90 \%$ \\
\hline & \multicolumn{3}{|c|}{ Of Particle have Diameters Less Than $(\mu \mathrm{m})$} \\
\hline Simulant with Flyash - No Sonication & 0.27 & 1.9 & 14 \\
\hline Simulant with Flyash - After Sonication & 0.26 & 1.7 & 13 \\
\hline
\end{tabular}

Scanning Electron Microscopy images of particles from the Water Clarity Simulant (captured on a 2- $\mu \mathrm{m}$ Nucleopore filter) and Energy Dispersive Spectroscopy (EDS) are shown in Figure 4. This figure confirms the simulant contains a broad range in particle sizes and shapes. While the particles shown in Figure 4 appear more structured than the uranium-rich and iron-rich particles in Figure 1 (actual K Basin suspended particulate), it is important to note that SEM captures only a very small subset of the particles available, and the particles examined may not be representative of the entire particle population.

\subsection{Example Basis for Total Quantity of Simulant Required for Testing}

Assume dry weight of simulant components $=100 \mathrm{X}$ the solids holding capacity of a 10 -in. filter element.

Solids holding capacity of potential filter $=50 \mathrm{~g} / \mathrm{ft}^{2}$ (example vendor value).

Filter surface area for 10 in filter cartridge $=5 \mathrm{ft}^{2}$ (example vendor value).

Dirt holding capacity of $10 \mathrm{in}$. filter cartridge $=250 \mathrm{~g}(50 \times 5)$.

Total Quantity of Simulant required $=25 \mathrm{~kg}(100 \times 0.25 \mathrm{Kg})$.

If simulant loading is prepared at $100 \mathrm{mg} / \mathrm{L}$, approximately 66,000 gallons of challenge solution could be made with $25 \mathrm{~kg}$ of dry components. 
PNNL-15615, January 23, 2006

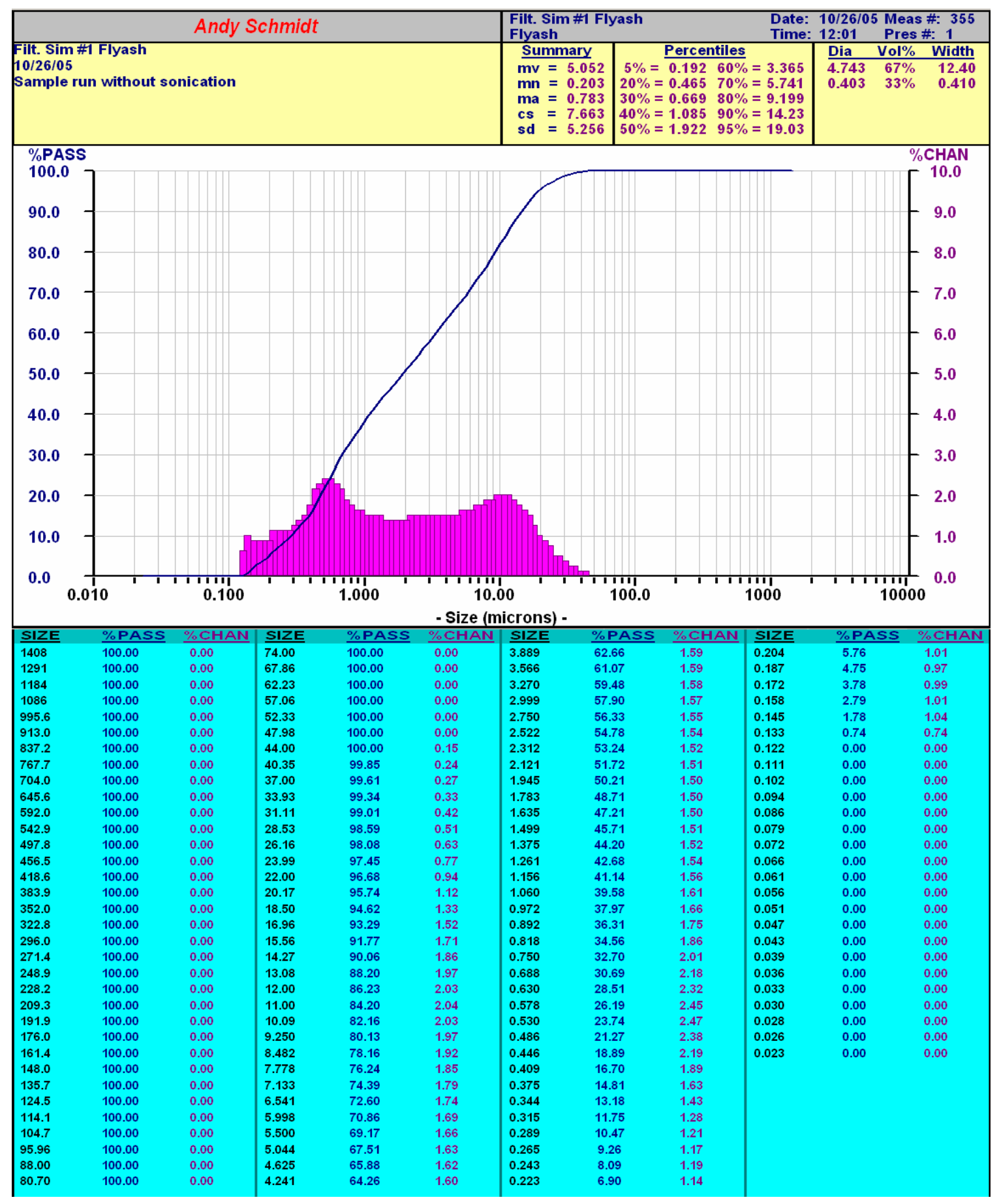

Figure 2. Water Clarity Filtration Simulant with Flyash - No Sonication 
PNNL-15615, January 23, 2006

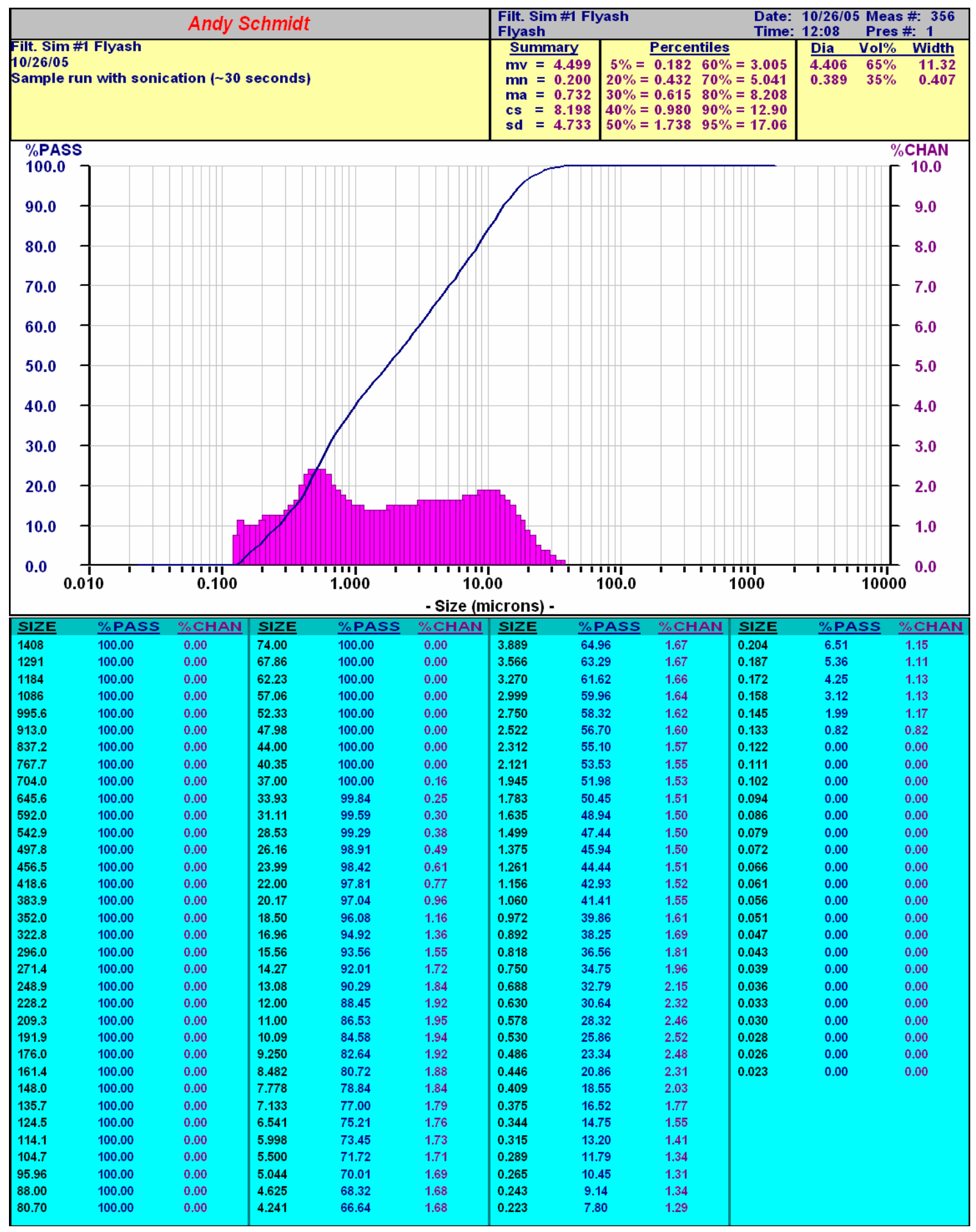

Figure 3. Water Clarity Filtration Simulant with Flyash - After Sonication 

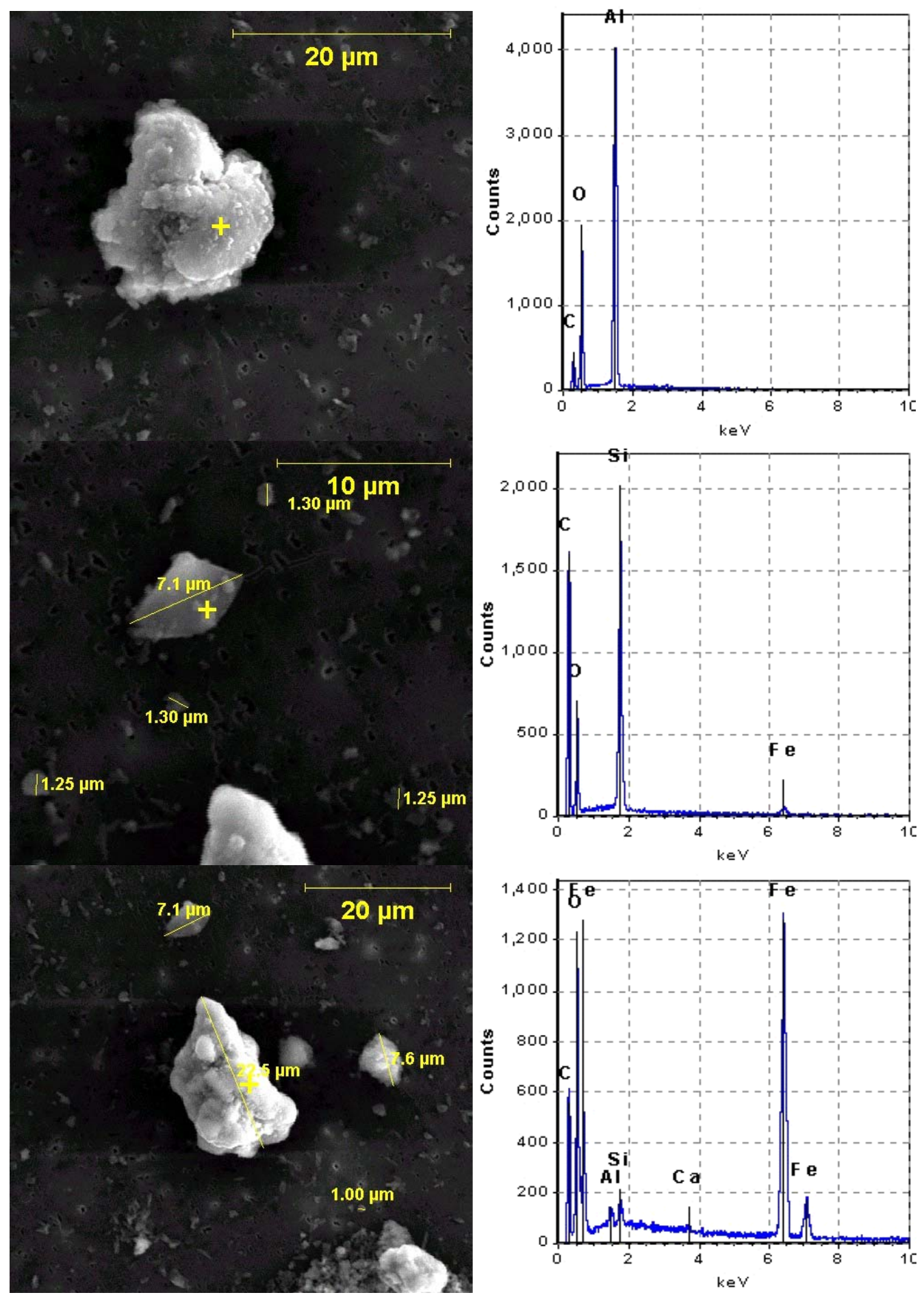

Figure 4. Scanning Electron Microscopy Images and Energy Dispersive Spectroscopy of Water Clarity Simulant Particles. Particles were captured on a $2.0 \mu \mathrm{m}$ (absolute) Nucleopore filter. The primary particle in the top image is aluminum-rich, the middle is silica-rich, and the bottom is iron-rich. SEM analysis was performed by Analytical Technical Services, Hanford. 


\subsection{References}

Crocker, JW. 2005. KE Sludge Containerization Equipment Developmental Testing Report - Project A21A. HNF-22813, Rev. 0, Fluor Hanford, Richland, WA.

Hecht, SL. 1999. System Design Description for Consolidated Sludge Sampler System for K Basin Floor and Fuel Canisters. HNF-3971, Fluor Hanford, Richland, WA.

Makenas, BJ, AJ Schmidt, KL Silvers, PR Bredt, , CH Delegard, EW Hoppe, JM Tingey, AH Zacher, TL Welsh, and RB Baker. 1999. Supplementary Information on K-Basin Sludges. HNF-2367, Rev. 0, Fluor Daniel Hanford, Inc., Richland, WA.

Makenas, BJ, TL Welsh, RB Baker, GR Golcar, PR Bredt, AJ Schmidt, JM Tingey. 1998. Analysis of Sludge from Hanford K West Basin Canisters. HNF-1728, Fluor Daniel Hanford, Inc., Richland, WA.

Makenas, BJ, TL Welsh, RB Baker, EW Hoppe, AJ Schmidt, J Abrefah, JM Tingey, PR Bredt, GR Golcar. 1997. Analysis of Sludge from Hanford K East Basin Canisters. HNF-SP-1201, DE\&S Hanford, Inc., Richland, WA.

Makenas, BJ, TL Welsh, RB Baker, DR Hansen, GR Golcar. 1996. Analysis of Sludge from Hanford K East Basin Floor and Weasel Pit. WHC-SP-1182, Westinghouse Hanford Company, Richland, WA.

Mellinger, GB, CH Delegard, AJ Schmidt, and GJ Sevigny. 2004. Evaluation and Recommendation of Waste Form and Packaging for Disposition of the K East Basin North Loadout Pit Sludge. PNNL-14741, Pacific Northwest National Laboratory, Richland, WA.

Plys, MG and AJ Schmidt. 2005. Supporting Basis for Spent Nuclear Fuel Project Sludge Technical Databook. SNF-7765, Rev. 3A, Fluor Hanford, Richland, WA.

Pearce, KL. 2001. 105-K Basin Material Design Basis Feed Description for Spent Nuclear Fuel Project Facilities Volume 2, Sludge. HNF-SD-SNF-TI-009, Volume 2, Rev. 4, Fluor Hanford, Richland, WA.

Schmidt, AJ. 2005. Spent Nuclear Fuel Project Technical Databook, Volume 2, Sludge.

HNF-SD-TI-015, Rev. 12a, Fluor Hanford, Richland, WA.

Shelor, JL, MG Plys, M Epstein, JP Sloughter, J Abrefah, CH Delegard, and AJ Schmidt. 2004. Gas Behavior in Large Diameter Containers (LDCs) during and following Loading with 105K East North Loadout Pit Sludge. SNF-22059, Revision 0, Fluor Hanford, Richland, WA. 